\title{
CUARENTA AÑOS DE MONARQUÍA PARLAMENTARIA
}

\section{(Balance)}

ANTONIO TORRES DEL MORAL 
SUMARIO

1. INTRODUCCIÓN. 2. DE LA DICTADURA FRANQUISTA A LA INSTAURACIÓN DE LA MONARQUÍA. 3. MONARQUÍA Y DEMOLICIÓN DEL RÉGIMEN FRANQUISTA. 4. MONARQUÍA Y CONSTITUCIÓN: 4.1. La Monarquía tras la promulgación de la Constitución. 4.2. Sistema sucesorio. Juramento. 4.3. Monarquía y Fuerzas Armadas. 4.4. Inviolabilidad y Corte Penal Internacional. 5. MONARQUÍA Y OPINIÓN PÚBLICA. 6. ABDICACIÓN DE JUAN CARLOS I. 7. DE PRÍNCIPE HEREDERO A FELIPE VI: 7.1. Aprendizaje del oficio. 7.2. Una monarquía renovada para un tiempo nuevo. 8. CRISIS CATALANA Y DERECHO DE MENSAJE. 9. DOCE RETOQUES A LA INSTITUCIÓN: 9.1 Planteamiento. 9.2. Sin necesidad de reforma constitucional. 9.3. Con reforma constitucional obligatoria. 


\title{
CUARENTA AÑOS DE MONARQUÍA PARLAMENTARIA
}

\section{(Balance)}

\author{
ANTONIO TORRES DEL MORAL ${ }^{1}$ \\ Catedrático de Derecho Constitucional
}

\section{INTRODUCCIÓN}

Hace treinta años, convocados los ponentes constitucionales para reflexionar en voz alta sobre los diez años de vigencia constitucional, Solé Tura, a quien profesé en vida una sincera amistad y compañerismo y, desde que nos dejó, un recuerdo emocionado, comenzó diciendo que «celebrar el décimo aniversario de una Constitución de signo democrático es en nuestro país un acontecimiento histórico»; y poco más adelante, añadió que «el consenso era... la respuesta a un problema políticamente muy importante y nada teórico» ${ }^{2}$. Estas dos contra-ideas estarán presentes a lo largo de las páginas que siguen.

Hace quince años, con ocasión de los primeros veinticinco de vigencia constitucional, hice un breve balance de esos mismos años de monarquía parlamentaria. Había monarquía desde tres años antes, pero no era una monarquía parlamentaria. Uno no resiste la tentación de hacer ahora otro tanto respecto de los años pasados desde entonces. Y a ello obedece esta contribución en homenaje a la Constitución, la mejor Constitución habida en España desde el punto de vista jurídico y político, porque proporciona, por lo general, soluciones plausibles a problemas complejos, incluso endémicos, de nuestro poco ejemplar constitucionalismo histórico. Otra cosa es el desarrollo legislativo ulterior de dichas opciones de nuestra Carta Magna.

${ }^{1}$ Catedrático de Derecho Constitucional. Facultad de Derecho. Universidad Nacional de Educación a Distancia. Obispo Trejo, 2. 28040 Madrid. Email: atorres@der.uned.es

${ }^{2}$ Solé Tura, J.: «Un balance diez años después», en VV.AA.: Diez años de Constitución, Ibercaja, s.l. y s.f.; págs. 103 y 104 . 
No han sido quince años de simple continuidad de la institución monárquica y de asentamiento constitucional de la política española. Tampoco fueron continuistas los veinticinco anteriores a poco que recordemos episodios de inquietud no ya solo para la forma monárquica de la Jefatura del Estado, sino también, con mayor evidencia, para el régimen democrático instaurado por la Constitución. En este segundo periodo convencional de tres lustros ha habido hechos y sucesos, incluso muy graves, respecto de problemas recientes o endémicos que merecen recordatorio y reflexión. No anticipemos, empero, el comentario.

También parece procedente que en alguna ocasión ampliemos la mirada hacia otras zonas que, de una u otra índole, terminaron afectando a la forma política monárquica por ser esta, por razones obvias, más sensible que la republicana a ciertos comportamientos, sucesos e incluso apariencias que afectan no solo al titular de la Corona, sino también a las personas de su Familia y Casa, todo ello en medio de una opinión nacional e internacional que aguardaba escéptica y temía que hubiera tensiones o incluso enfrentamientos en busca de la supremacía de una de «las dos Españas».

Finalmente, al estar dedicado este escrito a facilitar al lector una panorámica de 40-43 años de monarquía, parece obligado pedir excusas por la índole preferentemente descriptiva del texto, si bien hago las pertinentes remisiones a obras propias y ajenas en las que se contienen argumentaciones y precisiones conceptuales suficientes para el lector que las precise.

El esquema siguiente pretende sintetizar lo más señalado de las dos etapas:

$$
\text { 1975-1993 }
$$

$1994-2018$

\begin{tabular}{ll}
\hline \multicolumn{1}{c}{ Desmontar el régimen franquista: } & Aires de cambio político: \\
\hline - Cortes & -Supresión servicio militar obligat. \\
-Ejército & -Descenso partid. tradic. en Europa \\
- Ley para a Reforma Política & - Renovación clase política dirigente \\
- Legalización de los Partidos & \\
- Legalización del Partido Comunista & \\
-Elecciones constituyentes 1977 & \\
- Aprob. (referendo) de la Const. 1978 & - Emergencia de nuevos partidos polit. \\
- Emergencia clase pol. autonómica & -Sindicalismo de baja intensidad \\
- Legalización Sindicatos, etc. &
\end{tabular}




\begin{tabular}{|c|c|}
\hline $1975-1993$ & $1994-2018$ \\
\hline Crisis: & Crisis: \\
\hline — «Desencanto» & —Se agudiza la crisis de representación \\
\hline \multicolumn{2}{|l|}{ —Ejército - 23-F. Mensaje de JC-I } \\
\hline \multirow[t]{2}{*}{ —Crisis económica años 70} & —Crisis años 90 \\
\hline & —Crisis mundial sistémica (2008-2017) \\
\hline -Corrupción polit-econ. general & —Id. intensificada \\
\hline \multirow[t]{2}{*}{ —Crisis permanente: ETA } & —Continúa crisis ETA hasta 2011 \\
\hline & —Crisis Cataluña (2006-) \\
\hline \multirow[t]{6}{*}{ —Ref. const. 1992 Tr. de Maastricht (consenso) } & —Ref. const. 2011 art. 135 (controvertida) \\
\hline & —Crecimiento demanda reforma const. \\
\hline & —Creación de Corte Pen. Intern.(1998) \\
\hline & —Abdicac. Europa/España (2013-2014) \\
\hline & —Proclamación de Felipe VI (2014) \\
\hline & —Agudización crisis catalana (2017-) \\
\hline
\end{tabular}

\section{DE LA DICTADURA FRANQUISTA A LA INSTAURACIÓN DE LA MONARQUÍA}

Muchas son las advertencias acerca del riesgo que provoca el desconocimiento de pasado, de la propia historia. Si ese desconocimiento es voluntario, si es desentendimiento, el riesgo de incurrir en los mismos errores aumenta. Y algo de lo primero y de lo segundo ha sucedido en nuestro país por lo que se refiere a las formas políticas que han regido en España y a sus variantes.

Tales formas no se hacen permanentes en unos países y sufren variaciones en otros como si hubiera habido desde siempre una predisposición de los pueblos a unas o a otras o se cumplieran unas leyes perennes como geológicas, ni por obra de la fatalidad. Es la historia de cada pueblo la que facilita unas medidas y unas formas más que otras. Pero los aciertos y los errores solo son atribuibles a los humanos. Pues bien, como dijo Solé Tura en la ocasión citada, la historia de nuestro país, nuestra historia, configuró una monarquía profundamente oligárquica, militarista, clerical y cerrada que marginó a un amplio abanico de fuerzas democráticas de centro y de izquierda, que quedaron identificadas como antimonárquicas, republicanas ${ }^{3}$.

3 Solé Tura: J.: «Un balance...», ob. cit., pág. 107 
Si, teniendo presente nuestra historia como pueblo, era difícil que la monarquía pudiera rehacerse después de la dictadura de Primo de Rivera, también lo era que la salida del régimen de Franco Bahamonde fuera la reposición de la república, de una república que aquél había vencido con las armas. Tampoco eran favorables las perspectivas de instauración en España de un régimen democrático. Ni la Historia ni el presente invitaban al optimismo. La Historia porque el constitucionalismo español se caracteriza por los movimientos revolucionarios (o peudorrevolucionarios, más bien asonadas), lo que provocó una continua sucesión de «soluciones» que desembocó en una dictadura de 36 años políticamente inmovilista y con las Fuerzas Armadas como argumento disuasorio de cualquier pretensión innovadora.

El vencedor de la guerra, además, se inclinó por la monarquía, no sin jugar con unos y con otros alimentando falsas aspiraciones. En el sector falangista del régimen se especulaba con seriedad fingida acerca de una «salida» del régimen en forma de Regencias sucesivas, torpe simulacro de una república autista. Pero, como decía Aristóteles, las cosas tienden a su lugar natural y la desembocadura natural del régimen franquista no podía ser esa falsa ensoñación falangista.

La designación de Juan Carlos de Borbón como «sucesor a título de Rey», y su aprobación en las Cortes, con un buen puñado de votos negativos provenientes de los sectores falangista y sindical, tuvo lugar el 22 de julio de 1969. Por no faltarle nada a don Juan Carlos, tuvo incluso la oposición abierta de su padre, Conde de Barcelona, que reclamaba su mejor derecho a ocupar el trono; oposición que no cedió sino ante los hechos consumados, poco antes de las elecciones constituyentes de 15 de junio de 1977.

A la muerte del Caudillo, Juan Carlos I fue proclamado Rey con una escenificación penosa: ante unas Cortes nulamente democráticas que lo aceptaban por haber sido impuesto por el dictador; con un vacío casi absoluto de dignatarios extranjeros; con la criminalización de los partidos políticos, salvo el oficial; sin reconocimiento de derechos políticos ni de libertades públicas ni de garantías (lógicamente innecesarias), antes al contrario. Por su parte, las fuerzas políticas ilegales y clandestinas se manifestaban abiertamente en contra de la monarquía y a favor de la III República, en tanto que en la ciudadanía había más resignación que esperanza por considerar más probable el continuismo que el aperturismo.

En efecto, aunque nunca falta quien enuncie a posteriori evidencias sobre lo sucedido y conocido, lo cierto es que no hay ni un solo análisis basado en datos objetivos ni tampoco un pronóstico razonado sobre la evolución del régimen hacia una democracia homologable con las europeas. Lo que predominaba era o la expectación o la preocupación por entenderse que el Rey no podría salir del entramado institucional del franquismo.

A mi juicio, era un tanto forzada la calificación que el eminente sociólogo J. J. Linz hizo del franquismo de última hora como régimen autoritario, esto es, un régimen caracterizado por su desideologización, un pluralismo político limitado y la 
concentración del poder en un líder o en un grupo reducido ${ }^{4}$. En realidad, el pluralismo en el seno del franquismo era tan limitado que se reducía al existente dentro del partido único; la desideologización era un recurso dialéctico que oponer a la ideologización (generalmente de izquierda e incluso de extrema izquierda) de la oposición encarcelada, exiliada o clandestina; en cambio, la concentración del poder en el «Caudillo carismático e irrepetible» era máxima. Personas del régimen franquista, como Fraga Iribarne, aprovecharon dicha calificación y el prestigio de su autor para cantar las excelencias del régimen: un régimen autoritario ciertamente; es decir: un régimen con autoridad, como debe ser.

Dicho sea todo lo anterior sin desconocer la evolución de tal régimen durante su larga vigencia; no obstante, nunca dejó de ser, aunque en grado algo menor, totalitario. Las últimas ejecuciones de la pena capital en un contexto internacional que presionaba a favor de su conmutación y las magnas concentraciones en la madrileña Plaza de Oriente son solo unas muestras de la verdadera naturaleza del régimen. Lo que realmente se produjo en él fue más bien una diacronía entre el crecimiento económico y el cambio social, de un lado, y la falta de cambios y de modernización políticos, de otro 5 .

Sin embargo, ya iniciados los años setenta, se publicaron dos obras que explicaban las posibilidades jurídicas de rápida evolución hacia una democracia sin poner en peligro la convivencia siempre que pudiera contarse con la voluntad concorde de sectores significativos del franquismo.

Herrero de Miñón, en El principio monárquico, abogó por una democratización del régimen franquista de la mano del Rey con un ejercicio inteligente del principio que reza en su título aprovechando el poder que le conferían las Leyes Fundamentales ${ }^{6}$. Un año más tarde, el profesor de Esteban coordinó un dictamen sobre las posibilidades de una evolución acelerada hacia la democracia mediante un uso alternativo del Derecho, actitud teórico-práctica entonces muy defendida en círculos progresistas ${ }^{7}$. Aunque diferentes entre sí, las dos obras apostaban por una evolución acelerada a partir del sistema vigente como fórmula preferible a la revolucionaria o cuasirrevolucionaria de un proyecto constituyente genuino.

Y esta fue la vía seguida por el Rey, bien asesorado por los presidentes de las Cortes y del Gobierno, cargos para los que designó a personas de su confianza (Torcuato Fernández-Miranda y Adolfo Suárez González, respectivamente). El poder casi omnímodo heredado del franquismo («todos los poderes del nuevo Estado») fue utilizado para su demolición y construir en su lugar uno democrático. Dicho de otro modo, el régimen dictatorial facilitó al Rey las armas para que procediese a su des-

${ }^{4}$ LinZ, J. J.: «Una teoría del régimen autoritario. El caso de España», en la obra colectiva La España de los años setenta, Editorial Moneda y Crédito, Madrid, 1974, t. III, pág. 1474.

5 Tezanos, J. F.: «Modernización y cambio social en España», en la obra dirigida por el propio autor, R. Cotarelo y A. de Blas La transición democrática española, Sistema, Madrid, 1989, pág. 109.

${ }^{6}$ Herrero de Miñón, M.: El principio monárquico, 1972.

7 De Esteban, J., y otros: Desarrollo político y Constitución española, Ariel, Barcelona, 1973. 
guace y construyera uno de naturaleza democrática. Como ha escrito García López, el importante margen de acción que las Leyes Fundamentales del franquismo atribuían al Rey «facilitó considerablemente el proceso de desmantelamiento del sistema y además hizo que el Rey apareciera ante la nación como situado más allá del juego político» ${ }^{8}$.

Sin embargo, no era posible llevar a efecto la segunda parte de dicho recorrido, la construcción de una democracia, sin la colaboración de fuerzas políticas democráticas, porque ellas habrían de protagonizar el futuro. Como estaba muy extendido entre todos los interlocutores el deseo de sumarse al cambio y no quedar paralizados, se pudo llevar a efecto la empresa con un resultado favorable.

Sin intentar profetizar el pasado, sino utilizar su conocimiento a posteriori para encontrarle explicación, hemos de recordar cómo ya en el discurso de Juan Carlos I ante las Cortes en la ceremonia de su proclamación como Rey pudo escucharse, junto a la inevitable fraseología franquista, algunas afirmaciones de signo aperturista: se identificó como Rey de todos los españoles, afirmó que actuaría como moderador y que se respetaría la diversidad de pueblos que conforman la unidad española, así como el reconocimiento de los derechos sociales y económicos y el efectivo ejercicio de todas las libertades.

Por otra parte, era obvio que Estados Unidos y las potencias democráticas europeas no querían una repetición de la revolución portuguesa de 1974 y apoyaron una evolución controlada, que no subvirtiera el modelo de sociedad que se había gestado durante la última fase de franquismo, similar, aunque a distancia, del vigente en dichos Estados. No fue casual, por tanto, que el discurso pronunciado por el Rey unos meses más tarde en el Congreso de Estados Unidos, fuera más explícito y hablara de participación política de todos los ciudadanos sin discriminación alguna, de actuar bajo los principios de la democracia y con las alternativas de gobierno que el pueblo decidiera?.

Decisión que sintonizó tanto con los interlocutores foráneos como con la sociedad española, especialmente con los sectores progresistas, ya bastante crecidos, que aspiraban a la integración de España en la Europa democrática como la meta más deseable, «como el mejor seguro político de su supervivencia « ${ }^{10}$. Se repitió con insistencia un eslogan de muy expresivo laconismo: «España es el problema, Europa la solución».

Tezanos lo ha descrito con verisimilitud: «Ciertos sectores permanecían aún anclados en los esquemas del antiguo régimen, mientras otros eran cada vez más

${ }^{8}$ GARCía López, E.: «Apuntes para una relectura heterodoxa de a transición política española», Estudios de Deusto, Universidad de Deusto y Thomson Reuters Aranzadi, Madrid, 2013, pág. 147.

9 Cfr. Sánchez Navarro, A.: «Monarquía y transición política», en Gómez Sánchez, Y. (coord.): XXV años de monarquía parlamentaria, Sanz y Torres, Madrid, 2006, págs. 49 ss.

${ }^{10}$ GARCía López, E.: Apuntes para una relectura heterodoxa de la transición política española, Universidad de Deusto y Thomson Reuters Aranzadi, Bilbao, 2013, pág. 150. 
conscientes de lo ventajoso que resultaría... una democratización del sistema político que hiciera posible una mayor integración de España en el contexto capitalista internacional» ${ }^{11}$. En similar sentido apuntó Maravall que la política de compromisos estaba dictada por la fragilidad de la democracia, que sufría el azote de la crisis económica, del terrorismo, de la violencia de la extrema derecha y del temor continuo de involución ${ }^{12}$. Por eso, los partidos recién legalizados hubieron de tener en cuenta las actitudes políticas de la sociedad española en su conjunto, que eran más moderadas que las de sus militantes ${ }^{13}$, para facilitar la transición a la democracia. Como ha escrito S. Juliá, [1\}os años de desarrollo económico habían producido cambios notables en la cultura política de los españoles y favorecido la de un sector de la sociedad... habitantes de zonas urbanas y de más alto nivel de educación, más tolerante, más inclinado al pluralismo y opositor, por tanto, al régimen de Franco... ${ }^{14}$. Se imponía el posibilismo.

¿Cómo calificar entonces lo ocurrido: como una ruptura con el régimen franquista o como una reforma de este? Según escribió Morodo, la actitud rupturista de la Oposición respondía a razones estratégicas, no a su rechazo frontal de todo lo subsistente del periodo histórico anterior. Pues, efectivamente, ni cuestionó la monarquía ni el sistema económico ${ }^{15}$. A su vez, Cascajo caracterizó la transición como un brillante ejercicio de posibilismo político haciendo un uso alternativo de la legalidad franquista para llegar a la legitimidad democrática ${ }^{16}$.

Hernández-Gil, a la sazón Presidente de las Cortes Constituyentes, lo explicó diciendo que reforma y ruptura no se oponen entre sí: la ruptura es un resultado y la reforma un método. El método reformista tuvo al final un resultado rupturista como desembocadura de transformaciones acumuladas ${ }^{17}$. Por último, Cotarelo, con una mezcla de desencanto irónico y admiración, comentó en su día que el joven Rey transformó el referendo sobre monarquía o república, que hubiera sido muy peligroso, en un referendo sobre la Constitución monárquica. En cierto

11 Tezanos, J. F.: «La crisis del franquismo y la transición democrática en España», Sistema, Madrid, 1989, págs. 22-23.

12 Maravall, J. M.: La política de la transición, 2. edic., Madrid, 1984, pág.

13 Maravall, J. M., y Santamaría, J.: «Transición política y consolidación de la democracia en España», en Tezanos, J. F., Cotarelo, R., y Blas, A. de: La transición democrática española, Sistema, Madrid, 1989, pág. 203.

14 Juliá, S.: «Sociedad y política», en Tuñón DE LARA, M., y otros, Historia de España, vol X: Transición y democracia, Labor, Barcelona, 1992, pág. 48.

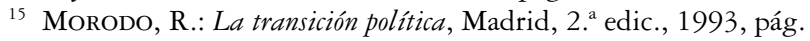

${ }^{16}$ Cascajo, J. L.: «Apunes sobre transición política y cultura constitucional: el caso español», Responsa Iusperitorum Digesta, vol. VIII, Salamanca, 2002, pág. 39.

17 Hernández-Gil, A.: El cambio político español, y la Constitución, Barcelona, 1982, pág. 122123. Más críticos sobre el resultado de la transición se mostraron en su día de Esteban y López Guerra (La crisis del Estado franquista, Labor, Barcelona, 1977, pág. 67), que la cifraron exclusivamente en una racionalización, secularización y reforzamiento de la supremacía del poder civil, con un resultado de incapacidad de los servicios públicos elementales —educación, sanidad, empleoque llevaron a una pérdida de legitimidad del Estado y una escasa integración de los conflictos. 
modo, el Rey le otorgó al pueblo una Constitución y la Constitución le otorgó un $\mathrm{Rey}^{18}$.

Entiendo, pues, con García López que Portugal protagonizó la última revolución de la modernidad y España la primera intervención de un proceso constituyente evolutivo sin rehacer de nuevo la sociedad ${ }^{19}$.

Pero la normalidad también pasaba por establecer relaciones con la URSS y países dependientes, las denominadas eufemísticamente «democracias populares». En efecto, a principios de 1977 se establecieron relaciones diplomáticas con la URSS y poco después fue legalizado el Partido Comunista. Con buena lógica, el presidente Suárez vinculó ambos hechos: «... sería paradójico que, cuando hemos establecido relaciones diplomáticas plenas con los países del Este, mantuviésemos al margen de la ley a aquellos comunistas del interior que aceptan una convivencia legal» ${ }^{20}$.

\section{MONARQUÍA Y DEMOLICIÓN DEL RÉGIMEN FRANQUISTA}

Como puede apreciarse, la principal diferencia entre los dos periodos fijados en el esquema inicial reside en que en el primero, máxime si lo retrotraemos al inicio del reinado de don Juan Carlos, la empresa política más importante consistió en liquidar el régimen anterior en medio de un ambiente no precisamente propicio, al menos en un principio. Diciéndolo simplificadamente, se montaba el régimen franquista sobre: a) el poder absoluto de Franco Bahamonde, en el que se concentraba el Ejecutivo y el Legislativo (este segundo hasta casi el final del régimen, justamente hasta 1967); b) unas Cortes «orgánicas», esto es corporativas, nutridas por procuradores, que así se llamaban, no elegidos por sufragio universal y que nunca tuvieron poder legislativo propiamente dicho y en exclusiva, y solo lo tuvieron, compartido con el dictador, a partir de la promulgación de la Ley Orgánica del Estado (1967); c) unos sindicatos «verticales», en los que, según la doctrina oficial, trabajadores y empresarios trabajaban juntos en pro del bien común; 4) la prohibición de partidos políticos, «intrínsecamente perversos», como los calificó el filósofo falangista Adolfo Muñoz Alonso, por lo cual la política había que hacerla dentro del Movimiento Nacional, que es el nombre que se daba al partido único sin llamarlo así; 5) y un Ejército absolutamente adicto al Jefe del Estado.

${ }^{18}$ Cotarelo, R.: «Visiones de la transición», Revista del Centro de Estudios Constitucionales, n. ${ }^{\circ} 18$, Madrid, 1994, pág. 19.

${ }^{19}$ GARcía López, E.: El Rey neutral: la plausibilidad de una lectura democrática del artículo 56.1 de la Constitución», Teoría y Realidad constitucional, UNED, Madrid, n. ${ }^{\circ}$ 34, pág. 152.

20 Powell, Ch. T.: «La dimensión exterior de la transición política española», Revista del Centro de Estudios Constitucionales, n. ${ }^{\circ}$ 18, Madrid, 1994, pág. 90. 
Poco a poco, en los primeros años de la transición se fueron desmontando esos pilares, algunos de los cuales, como los sindicatos, eran muy poco consistentes y estaban ampliamente desbordados por los sindicatos reales, que eran clandestinos y delictivos conforme a la entonces vigente legislación penal. La empresa política de construir un edificio democrático y constitucional pasaba por la demolición de lo existente y su sustitución por instituciones comunes a las de las democracias europeas, con las que España debía y quería aliarse. La pieza jurídica sobre la que pivotó dicho proyecto hasta la promulgación de la Constitución fue la Ley para la Reforma Política, aprobada en referendo en diciembre de 1976 y vigente desde enero de 1977. A partir de ella, que respondía ya al principio de soberanía popular, fueron legalizados los sindicatos propiamente dichos y los partidos políticos y se convocaron elecciones a Cortes (que habrían de ser constituyentes), cuyo resultado significó una renovación importante de la clase política y una incorporación parcial del personal político del régimen anterior al régimen democrático que comenzaba a construirse.

La crisis de los años setenta, conocida como «crisis del petróleo», azotaba España. Para hacerle frente, los partidos políticos emergentes de las elecciones constituyentes de 15 de junio de 1977 suscribieron los denominados Pactos de la Moncloa, uno de carácter político, y otro de signo económico-social, con principios y criterios que habrían de guiar la labor gubernamental hasta ser aprobada la Constitución. Si no fuera porque el concepto de Constitución material aun no está teóricamente fijado ${ }^{21}$, podríamos decir que estos Pactos fueron la Constitución material española durante un año y medio, como punto intermedio en el proceso de elaboración de una Constitución formal democrática. Distinto fue, sin embargo, su seguimiento, muy irregular y sin verdadero control parlamentario ${ }^{22}$.

La crisis económica y la lentitud con que trabajó, primero, la Ponencia constitucional y, después, el Congreso y el Senado dieron origen a un fenómeno de desmoralización que se dio en llamar popularmente desencanto ${ }^{23}$. Desencanto social que, unido al que germinó en las altas capas del Ejército, en los diferentes cuerpos policiales y en los sectores económicos, amenazaba seriamente el buen fin de la empresa acometida.

Es posible, probable, e incluso seguro, que en el juego de compromisos y consensos, y de renuncias mutuas, las formaciones de la izquierda cedieran más que sus oponentes de la derecha durante la transición y particularmente en la redacción

${ }^{21}$ Mortati es reconocido como el teórico de la Constitución material, seguido por una gran mayoría de constitucionalistas italianos, pero no tanto en el resto de Europa; cfr. su obra La Constitución en sentido material, edic. esp., CEPC, Madrid, 2000.

${ }^{22}$ Desde el punto de vista jurídico todo parecía ser provisional en espera de la aprobación de la Constitución. Así, por lo que a las relaciones entre las Cortes y el Gobierno, ni este podía disolver las Cámaras, ni estas censurar al Gobierno.

${ }^{23}$ Luis García San Miguel escribió sobre este fenómeno con tacto, no exento de melancolía o de su propio desencanto, en Teoría de la transición, Editora Nacional, Madrid, 1981. 
del texto constitucional. Eso puede ser debido, en parte, a tácticas y dotes de persuasión de los negociadores, pero sobre todo a la relación de fuerzas existente entre ellos. De ahí que me parezca poco realista la valoración que en su día hizo $\mathrm{R}$. del Águila Tejerina, en la que resaltaba las mayores cesiones de las formaciones políticas de izquierda ${ }^{24}$. De hecho, como subraya García López, «en democracia, la necesidad de acuerdo no acaba nunca» ${ }^{25}$. Y, aunque durante la transición todos los negociadores sentían necesidad de superar la situación, lo cierto es que el centro-derecha tenía el Gobierno y esa posición produce cierta ventaja negociadora, aunque sea limitada.

El referido conjunto de causas motivó que la participación en el referendo nacional para la aprobación del texto constitucional fuera menos nutrida de lo que había sido unos meses antes para la aprobación de la Ley para la Reforma Política, no obstante lo cual, superó con creces los estándares que la doctrina estima legitimadores del objeto o decisión que, en forma de pregunta, se somete al pueblo como titular de la soberanía. He aquí algunos datos susceptibles de una no difícil reflexión:

\begin{tabular}{lcc}
\hline & $\%$ de votos & \\
\hline & afirmativos & negativos \\
\hline Canarias: & 91,89 & 4,36 \\
Andalucía: & 91,85 & 5,48 \\
Murcia: & 90,77 & 6,21 \\
Cataluña: & 90,46 & 4,61 \\
Madrid: & 86,14 & 10,11 \\
\hline TOTALES & 87,87 & 7,84 \\
\hline
\end{tabular}

España ingresó en el Consejo de Europa (1977), lo que significaba un compromiso serio de respeto y garantía de los derechos; en la OTAN (1981), con lo que se alineaba con Occidente en materia de Defensa, y en la Comunidad Económica Europea, hoy Unión Europea (1986), un Club que tantos beneficios ha reportado a nuestro país. La democracia española obtuvo el reconocimiento general de Occidente como Estado democrático y aliado.

24 Águia Tejerina, R. del: «La Transición a la democracia: Reforma, ruptura y consenso», Revista de Estudios Políticos, Centro de Estudios Constitucionales, n. ${ }^{\circ} 25$ (Nueva Época), Madrid, 1982, passim.

25 García López, E.: «El Rey neutral...», ob. cit., pág. 307. 


\section{MONARQUÍA Y CONSTITUCIÓN}

\subsection{La Monarquía tras la promulgación de la Constitución}

Aprobada y promulgada la Constitución, el Rey siguió una línea de monarca parlamentario con escasa intervención, si alguna, pero con auctoritas reconocida por todo lo actuado.

Las monarquías europeas, con la consabida excepción de la británica, tardaron más de un siglo en pasar de su versión absoluta a la parlamentaria. España tardó tres años y catorce días en aprobar la Constitución vigente mediante referendo popular; dicho sea para resaltar debidamente el mérito de la clase política que protagonizó la transición a la democracia ${ }^{26}$.

La aceptación de España, de la Constitución y del Rey en todo el mundo fue muy rápida y el texto recién aprobado influyó, en todo o en parte, en algunos iberoamericanos. Cuando hoy circulan sobre nuestro texto fundamental y sobre la monarquía no ya juicios adversos, sino totalmente descalificadores, me resisto a creer que todos los organismos internacionales y supranacionales que le fueron favorables se pusieran de acuerdo en equivocarse.

Don Juan Carlos, que había sido recibido con reticencias tanto por el régimen franquista como por las fuerzas políticas emergentes durante la transición, pronto fue aceptado por estas como pieza ineludible para el cambio político. Reconocimiento que se incrementó tras su intervención en la frustración del golpe de Estado de 23 de febrero de 1981. La institución gozaba de la admiración y afecto de la ciudadanía por sus relevantes servicios al país en momentos delicados y por la corrección de sus integrantes, pero también concitó un importante prestigio internacional, al que contribuyeron igualmente los medios de comunicación europeos. El rey recibió el premio Carlomagno en 1982.

No obstante, actualmente se lee y se oye con frecuencia la opinión oficiosa de que la actual monarquía española es la monarquía de siempre, con su misma dinastía, la monarquía de la Restauración, rodeada de oligarcas y caciques, radicalmente ilegítima. Enjuiciar instituciones pasadas, normas y regímenes con criterios actuales resulta anacrónico. Pero, por el envés, tampoco comparto la versiones «buenistas» que hacen converger en la monarquía actual todas las legitimidades imaginables.

El núcleo de la regulación constitucional de la monarquía reside en los artículos 1.3 y 56.1. El primero dice: «La forma política del Estado español es la monarquía parlamentaria». Precepto en el que se dan cita dos principios secularmente antagónicos (monárquico y democrático), pero finalmente convergentes precisamente en esta forma última y racionalizada de la monarquía: la parlamentaria. Con la particularidad

${ }^{26}$ Valga una muestra. Como es sabido, Santiago Carrillo llevó al Partido Comunista a aceptar la monarquía y la bandera española oficial (no la republicana que utilizaba el partido). Tuve varias conversaciones con él y en una de ella le pregunté cómo dio ese paso que le proporcionó algún adversario en su propio partido. Respuesta: «Porque vi que la esto iba en serio». 
de que, conforme a un somero análisis del articulado, avalado por cuarenta años de práctica constitucional, el principio monárquico no tiene otro reflejo en la Constitución que este precepto pues en todos los demás en que aparece el Rey siempre lo es, conforme al artículo 56.3, con el refrendo de otro órgano (normalmente el Presidente del Gobierno o un ministro) que hace suyo el acto y la responsabilidad consiguiente, si la hubiere. El principio monárquico, que tan útil fue en la transición del franquismo a la democracia, quedó desplazado por el principio democrático, que, como dice atinadamente García Canales, es el «único con relevancia jurídica por ser principio hermenéutico e inspirador del conjunto institucional» ${ }^{27}$.

En realidad, nada que no exista en el resto de las monarquías parlamentarias europeas. El corte con la monarquía programada por el franquismo no puede ser más elocuente. Al final, como comenta García López, la Constitución ha incorporado una monarquía parlamentaria que habla el lenguaje de la democracia ${ }^{28}$.

\subsection{Sistema sucesorio. Juramento regio}

Como ha señalado F. de Carreras, en cuanto a la forma política monárquica que habría de consagrarse en el texto constitucional, lo que en el fondo «se exigía por parte de unos era que el titular de la Jefatura del Estado siguiera siendo el Rey y, por parte de otros, que el contenido esencial de la Constitución — su forma de Estado y de gobierno, sus derechos fundamentales y su organización territorial- fuera republicano, en el sentido democrático y social del término. La monarquía parlamentaria permitía satisfacer a ambas partes» ${ }^{29}$.

Pérez-Llorca lo ha relatado muy explícitamente. Hubo en la Ponencia un debate temprano sobre la monarquía, lo cual despertaba «sentimientos no necesariamente coincidentes». Había un natural recelo lógico, ideológico e histórico de los ponentes de la izquierda en tanto que los ponentes «ministeriales» pretendían eludir un gran debate $^{30}$. Los partidos Comunista y Socialista mantuvieron su postura republicana pero aceptaron la monarquía reinante, en tanto que los nacionalistas minoritarios se manifestaron republicanos o pidieron testimonialmente un referendo sobre esta cuestión, si bien valoraban positivamente la gestión del Rey ${ }^{31}$. Dicho consenso se vio

27 García Canales, M.: La Monarquía parlamentaria española, Tecnos, Madrid, 1991, pág. 156.

28 García López, E.: «El Rey neutral...», ob. cit., pág. 303.

29 Carreras, F. de: «Significado constitucional dela monarquía parlamentaria», en Tusell, J., Lario, A., y Portero, F. (eds.): La Corona en la Historia de España, Biblioteca Nueva, Madrid, 2003, pág. 227.

30 PÉrez-LlorcA, J.-P.: «El Rey y las relaciones internacionales», en VV.AA.: La Monarquía Parlamentaria, Congreso de los Diputados, Madrid, 2005, pág. 240.

31 Un referendo, decían, que lavara a la Monarquía, si lo ganara, del pecado original franquista. Pero reconocieron la alta consideración que les merecía la persona y la actuación del Rey. 
estimulado además por el tipo de monarquía auspiciada, «muy poco monárquica», una monarquía como magistratura simbólica ${ }^{32}$.

Aprobada, sancionada y promulgada la Constitución, el Rey Juan Carlos no la juró. La Constitución española no prevé otros juramentos que el del Rey al ser proclamado, el del Príncipe de Asturias al llegar a la mayoría de edad y, en su caso, el del Regente al acceder al cargo. Comoquiera que Juan Carlos I ya había sido proclamado, se entendió que no procedía a repetir la ceremonia. Dice López Guerra que «[e] 1 hecho de que D. Juan Carlos I no jurase, aunque sí sancionase, la Constitución de 1978 no deriva de una posición de tipo "moderado", sino simplemente de que la Constitución se configura formalmente como una reforma de la legalidad constitucional anterior, que ya había sido jurada por el Rey» ${ }^{33}$.

Esto tuvo un doble efecto: de una parte, quedó como único juramento suyo el que prestó a los Principios Fundamentales del Movimiento y demás Leyes Fundamentales franquistas; de otra, se evitaba que emitiera un juramento contrario al que había emitido tres años antes. Valorados los dos posibles efectos, no parece totalmente desafortunada la decisión.

\subsection{Monarquía y Fuerzas Armadas}

Aún habría de rendir la Monarquía instaurada un serio servicio a la democracia interviniendo en la frustración del golpe de Estado del 23 de febrero de 1981. Como ha escrito Sabino Fernández Campo, dicha intervención «y, sobre todo, el consejo de guerra de ella derivado, tuvieron grandes repercusiones para la institución monárquica, que se robusteció y consolidó notablemente, mientras que no puede decirse lo mismo con respecto a la moral y al futuro de las Fuerzas Armadas españolas». Algo de amargura se percibe en estas palabras, por lo demás, desacertadas en el negro augurio sobre las Fuerzas Armadas ${ }^{34}$. Pero, en definitiva, Juan Carlos I vio exponencialmente incrementado su crédito en la opinión pública.

En tal episodio asumió el Rey, de hecho, todo el poder, pero precisamente para hacer posible que lo recuperaran los órganos constitucionales titulares del mismo, como hizo de inmediato en cuanto fue posible ${ }^{35}$.

Por otra parte, durante años hubo polémica sobre la supresión del servicio militar obligatorio. Finalmente lo decidió el primer Gobierno Aznar en 1998 por lo que, desde entonces, el Ejército español es total y estrictamente profesional. Como escribe Sabino Fernández Campo, fue Pi i Margall el inspirador directo de la idea de un

32 PÉrez-Llorca, J.-P.: «El Rey y las relaciones internacionales», ob. y lug. cits.

33 López Guerra, L.: «Artículo 61: Juramento», en Alzaga, O.: (dir.): Comentarios a la Constitución Española de 1978, Cortes Generales y Edersa, t. V, Madrid, 1997, pág. 205, nota 22.

${ }^{34}$ Fernández CAmpo, S.: «Consideraciones jurídico-constitucionales sobre los acontecimientos del23 de febrero de 1981», en Escritos políticos y morales, Ediciones Nobel, Oviedo, 2003, pág. 252.

35 Ibidem, pág. 264. 
ejército profesional, voluntario y poco numeroso, y de que solo debe ser obligatorio el servicio militar en épocas de guerra para sostener la autonomía de la nación. La sorpresa, no obstante, se explica por los antecedentes militaristas del régimen anterior y por el signo político conservador del Gobierno que tomó la decisión, nada reacio a la utilización de las armas cuando, con razón o sin ella, consideró que era llegado el momento. Acaso por eso no se desató la polémica y el Ejército se acomodó a esta nueva concepción y diseño ${ }^{36}$.

\subsection{Inviolabilidad y Corte Penal Internacional}

En 1998 se creó la Corte Penal Internacional, cuyo objeto es el enjuiciamiento de los crímenes de guerra, de lesa humanidad y de genocidio, uno de cuyos objetivos es el de acabar con la impunidad de altos jerarcas protegidos por estatutos especiales de inviolabilidad. Desde primera hora se planteó la duda sobre su compatibilidad con la inviolabilidad que la Constitución española reconoce al Rey. A este despecto, el Consejo de Estado dictaminó que la exigencia de responsabilidad derivada de los delitos que menciona el Estatuto, sin excluir a Jefes de Estado, es compatible con la Constitución: «Si la inviolabilidad parlamentaria se funda en la protección de la libertad de expresión de los parlamentarios... la del Jefe del Estado se fundamenta en su posición, ajena a toda controversia, dado el carácter debido de sus actos en el modelo constitucional de 1978». Y añade el dictamen que no se puede hablar en este último caso de ausencia absoluta de responsabilidad pues el acto que pudiera imputarse al Rey lo será al titular del órgano refrendante conforme a los artículos 56.3 y 64.2 de la Constitución ${ }^{37}$.

En un primer momento pudiera parecer que dicho dictamen bordea el problema sin afrontarlo pues ni el refrendo puede exonerar de culpabilidad penal actos del Rey tanto menos cuanto más graves sean, ni es fácil encontrar refrendante en tales supuestos. Sin embargo, lo inusual e improbable es que los titulares de las monarquías parlamentarias conocidas, y entre ellas la española, tengan margen de acción suficiente como para acometer políticas del cariz de los actos repudiados por el Estatuto de la Corte. Estas políticas, si fueran efectivas alguna vez, estarían decididas por los Gobiernos, que son los órganos de dirección de la política militar y de defensa; y la responsabilidad penal habría de ser identificada en ese ámbito.

Para otro tipo de actos delictivos su reparación habría de sustanciarse ante la justicia interna. Y es, por tanto en tal eventualidad en la que, para bien o para mal, entra en juego la inviolabilidad del Rey y cuando tendría sentido poner en juego todos los reproches que ciertos juristas (Gimbernat, Martín Pallín...) hacen al vigente estatuto jurídico del monarca. Solo si, en una improbable hipótesis, estos actos se

\footnotetext{
36 Ibidem, págs. 221 ss.

37 Dictamen 13/1998, del Consejo de Estado sobre la ratificación por España del Estatuto de la Corte Penal Internacional.
} 
encuadraran en el contexto de una guerra o de una política xenófoba o terrorista podría intervenir la Corte Penal Internacional.

Por lo demás, siempre está abierta la puerta de la abdicación (sugerida o forzada) en las monarquías y del acuerdo en las repúblicas (caso Nixon) como forma imperfecta de responsabilización y como muestra de que los estatutos de los jefes de Estado en monarquías y en republicas, tan distantes en la literalidad de los preceptos, no lo están tanto en la realidad de los hechos ${ }^{38}$.

\section{MONARQUÍA Y OPINIÓN PÚBLICA}

La monarquía depende mucho de que sus «profesionales» crean en ella. Si ellos la cuestionan con sus hechos, nadie va a apuntalarla. Porque la monarquía se nutre de creencias y estas necesitan un soporte: un Rey y un aspirante preparado para tomarle el relevo. A veces no basta con eso porque personas allegadas, miembros de la Dinastía y del entorno estrecho de la familia regia y con expectativas sucesorias, aunque sean lejanas, se dedican no tanto a nutrir el patrimonio moral familiar y dinástico cuanto a aprovechar su posición para obtener privilegios en el mundo económico y financiero buscando incrementar sus cuentas corrientes de modo dudoso y, a veces , ni siquiera dudoso.

La monarquía no escapa a la férrea ley de la opinión pública, incluso está sometida a ella de forma singular y más incisiva que la república porque ésta tiene un recambio institucional ordinario y eso no sucede en igual medida en las monarquías. Por eso, estas son mucho más sensibles al descrédito de sus titulares y del de las personas integrantes de la Dinastía, porque puede arrastrar tras de sí a la propia monarquía como forma política ${ }^{39}$.

Las encuestas de opinión internas daban a la monarquía la puntuación más alta de entre todas las instituciones. Y así se mantuvo durante muchos años. Creció el juancarlismo, fenómeno que tenía doble lectura puesto que era un prestigio personal más que de la Institución. No era infrecuente oír en privado y en público que se era más juancarlista que monárquico, lo cual no tenía nada de positivo para esta forma política. Por lo demás funcionaba un «pacto de silencio» entre la Casa del Rey y los órganos de opinión, conforme al cual estos publicaban informaciones acordadas o servidas desde la Casa de Su Majestad.

Todavía en marzo de 2004, casi treinta años después del acceso de Don Juan Carlos al Trono, The Independent publicó una separata dedicada a la Familia Real de

38 Me he pronunciado sobre este asunto con algún mayor detenimiento en «Regeneración de la Monarquía», en Arnaldo Alcubilla, E., y GonZÁlez-Trevijano, P. (dirs.): En pro de la regeneración política de España, Fundación Universidad Rey Juan Carlos, Fundación Canal Isabel II y Thomson Reuters Aranzadi, Madrid, 2015, págs. 430-431.

39 Cfr. mi trabajo «Monarquía, democracia y opinión pública», en la obra dirigida por mi mismo Monarquía y Constitución, ob. cit., págs. 574-576. 
España con el siguiente titular: «Soberanos modelo. Lo que los Reyes de España pueden enseñar a los Windsor» ${ }^{40}$.

Sin embargo, comenzaron a suceder acontecimientos y a realizarse actos que se separaban un tanto de lo que la opinión pública esperaba, pero que fueron bien asumidos por dos motivos: porque eran «normales» en una sociedad democrática avanzada, como los matrimonios de las infantas Elena y Cristina. En cambio el primer noviazgo conocido de Don Felipe de Borbón sí dio pábulo a la opinión pública y los medios de comunicación se posicionaron al respecto.

Distinto fue el triste episodio vivido con ocasión del nuevo noviazgo o relación sentimental del Heredero con la ciudadana noruega Eva Sannum, recibido por la opinión pública con una drástica división de opiniones. Los medios de comunicación dieron por finalizado el «pacto de silencio» supuestamente vigente hasta entonces y, a partir de dicho affaire, tomó los asuntos de la Casa y Familia regias como objeto prioritario de información y de opinión. El Heredero dio por finalizada la relación y se mostró profundamente afectado. Se iniciaba una segunda época en la que la monarquía pasaba de ser objeto de trato deferente por los medios a ser pasto de las tertulias más diversas.

Nada conviene menos a una monarquía que andar en boca de todos. No es que yo quiera reivindicar para los reyes, familiares y deudos algo así como la sequía informativa y la opinión dirigida, o resucitar un remedo de los arcana regni, pero es lo cierto que la monarquía soporta peor que la república estar a diario en los medios de comunicación.

Ya en discusión el prestigio personal de Don Juan Carlos y de la monarquía, aún bajó más hasta quedar bajo mínimos cuando se informó por los medios, sin ulterior desmentido, acerca de su participación en una irregular jornada de caza en Rusia, a donde acudió, según parece, sin conocimiento del Gobierno, y poco después en una cacería de elefantes en Botsuana, de nuevo sin conocimiento del Gobierno y donde, acompañado de amante más o menos estable, sufrió una lesión de la que hubo de ser asistido a su regreso a España. El ambiente se tornó hostil, lo cual se vio acrecentado con las dificultades judiciales de la infanta Cristina, sexta persona integrante del orden sucesorio en la Corona, y su esposo, señor Urdangarín, investigados ambos cónyuges por delitos contra la Hacienda Publica. El 3 de mayo de 2013 Efe distribuyó la siguiente noticia: «Los españoles sitúan la monarquía por primera vez entre sus preocupaciones». Fue creciendo la opción republicana en las encuestas.

Ciertamente el reinado de Juan Carlos I ha sido muy dilatado y no puede sorprender que en él haya habido altibajos. Pero lo cierto es que la opinión pública pasó en breve tiempo de adjudicar a la monarquía un $7^{\prime} 5$ sobre 10 a darle un 3'5, puntuación crítica a la que, como veremos de inmediato, únicamente le faltaba la emergencia de otro factor adverso (otro más) para hacer insostenible la continuación del titular de la Corona.

40 Apezarena, J.: Felipe y Letizia. La conquista del Trono, La Esfera de los Libros, Madrid, 2014, pág. 388. 


\section{ABDICACIÓN DE JUAN CARLOS I}

Varios años antes de que se desencadenara esta espiral negativa acerca del Rey reinante y (por derivación, aunque menos) de la monarquía, escribí contra corriente:

«La sucesión en la Corona genera siempre una situación delicada, aunque no necesariamente preocupante. A mi juicio, la posibilidad de que el Rey — nuestro Rey, por ejemplo - abdique con 70 o 75 años ( o cuando se considere oportuno), además de permitir a éste disfrutar de la tercera edad, facilitaría una renovación más rápida de la Monarquía y su más fácil conexión generacional con la sociedad. Las abdicaciones habidas en las monarquías europeas en los últimos cincuenta o sesenta años... son buen ejemplo de ello. En cambio, la posición del Príncipe Carlos de Inglaterra es un punto menos que patética.

La abdicación comporta además la supervivencia de la figura del Rey-padre ( o Reina-madre), como imagen de auctoritas y de continuidad monárquica. En todo caso, la sucesión por abdicación es menos traumática que la debida a la muerte (acaso con una prolongada agonía) del titular de la Corona ${ }^{41}$ :

No tengo que aclarar que este comentario fue sumido en el más elocuente silencio. No sólo ya por los protagonistas de la Familia Real, sino también por los informadores y opinadores sobre estas cuestiones. Estoy bien seguro, sin embargo, de que no se trata de una herejía, como así se demostró empíricamente poco después. Se sucedieron declaraciones como «No se contempla esa eventualidad», «los reyes mueren como tales en la cama» y otros estereotipos muy interiorizados por aquel entonces en la Casa del Rey, con la consiguiente descalificación del discrepante.

Ciertamente esta evidencia no se impuso como un fenómeno de la naturaleza, como se suceden las estaciones a lo largo del año. La abdicación tardó unos años no sin seria resistencia del Rey hasta el último instante. En efecto, Juan Carlos I reprodujo en su mensaje de Navidad de 2013 su firme resolución de continuar al frente del Estado. Pero, como dice Paul Preston, ya el principal problema de la monarquía había pasado a ser garantizar su continuidad, esto es, asegurar la sucesión del Príncipe ${ }^{42}$.

Más aún, el día 5 de enero del año entrante, durante la celebración de la Pascua Militar, el Rey fue incapaz de leer el texto que traía preparado y tampoco supo recomponer la situación. Era la viva imagen de «fin de época», de inmediata abdicación. Algunos la reclamamos respetuosamente. Que fuera negado por el propio Rey no logró convencer a muchos ni, desde luego, a quien esto escribe: una somera reflexión sobre lo acontecido llevaba a la conclusión del agotamiento de un reinado y el necesario comienzo de otro; con la desventaja de que eso iba a suceder de modo forzoso o

41 Torres del Moral, A.: El Príncipe de Asturias. Su estatuto jurídico, Congreso de los Diputados,



42 Preston, O.: Juan Carlos, el Rey de un pueblo, 3. ${ }^{a}$ edic. actualizada, Debolsillo, Barcelona, 2014, págs. 599-600. 
poco menos y no como el relevo ordinario entre dos personas plenamente capaces y por razones de utilidad calculada.

Los estímulos finales que agrietaron el ánimo de Don Juan Carlos más allá de lo soportable seguramente tuvieron mucho que ver con sus circunstancias personales de edad y delicado estado físico en medio de varias abdicaciones habidas en monarquías europeas. Pero acaso nada de lo narrado habría vencido la tan enfáticamente anunciada resistencia regia a la abdicación si los resultados de las elecciones al Parlamento Europeo celebradas el 25 de mayo de 2014 no hubieran reflejado un descenso grave, hasta quedar en minoría, de los dos partidos principales a manos de formaciones políticas de juvenil ímpetu y republicanas en ejercicio. Una extrapolación de tales datos a elecciones nacionales dejarían a la Monarquía española sin la mayoría de apoyo que había tenido durante casi cuarenta años. Juan Carlos I abdicó unos días más tarde.

La observación anterior tiene más que ver con el Partido Socialista Obrero Español por su histórica alineación con la forma política republicana y por la reivindicación, todavía minoritaria, entre sus filas de dicha «seña de identidad».

El cambio de titular de la Corona ${ }^{43}$ evidenció que no existía una ley orgánica que regulara la abdicación. Meses antes esbocé yo un modelo de procedimiento a seguir desde que el Rey decide abdicar hasta que se consuma la operación ${ }^{44}$. Sin embargo, he de decir que no se hizo mal y que la ley promulgada al efecto puede servir de modelo para futuras ocasiones aunque con algunas correcciones y adiciones.

Menos bien quedó la «gestión»: el Rey Juan Carlos lo comunicó al Presidente del Gobierno, al líder de la oposición y a alguna persona más; luego a la ciudadanía a través de radio y televisión y solo después a los presidentes de las Cámaras, lo que se compadece mal con el carácter parlamentario de la monarquía española.

Con tal ocasión se desempolvaron algunos escritos sobre este instituto, en los que se pudo apreciar el conservadurismo del mundo jurídico, apegado a «lo de siempre», que es lo conocido y lo seguro, sin plantearse siquiera si la monarquía y el Ordenamiento jurídico son hoy iguales o diferentes de los del pasado, y, si son diferentes, en qué lo son.

Digo esto porque volvieron a aparecer en la tribuna pública o en seminarios universitarios el carácter de acto personalísimo de la abdicación y, por tanto, la necesidad de que la ley en la que se plasma sea de mera formalización del acto regio por ser este completo en sí mismo; en consecuencia, según esta tesis, tal ley de abdicación sería insusceptible de enmienda o de rechazo por las Cortes.

Quienes así dogmatizaron no reparaban en que puede haber circunstancias que recomienden no abdicar; más aun, habrá circunstancias que impidan abdicar y así lo debería establecer la correspondiente ley orgánica cuando la haya. Por poner

43 Con más detenimiento he tratado este instituto en el trabajo citado «En torno a la abdicación», págs. $18-28$.

44 En los archivos de Radio Nacional de España debe haber archivado un microespacio en el que, con varios meses de antelación, esbocé yo un modelo de procedimiento a seguir en la abdicación. 
algunos ejemplos, mencionaremos: a) los «tiempos de guerra»; b) el estado de sitio o el de excepción; c) estar la nación en pleno proceso de reforma constitucional, máxime si afecta a norma o normas relativas a la Jefatura del Estado o a alguna función regia; d) si se ha solicitado (=exigido) un referendo de reforma constitucional; e) si el Heredero o Heredera se encuentra en estado crítico de salud; f) mientras se encuentra en trámite una separación, divorcio o disolución del vínculo matrimonial del/de la titular de la Corona por la repercusión que esta circunstancia puede tener en el instituto de la Regencia, etcétera. Consiguientemente, sería deseable incorporar algunas de estas previsiones (mejor todas) al Ordenamiento español, justo en esa ley general de las abdicaciones, renuncias y circunstancias de la Familia Real que puedan afectar a la institución y, por derivación, a la Nación y al Estado.

Como he indicado, la abdicación de Juan Carlos I ha venido a coincidir con otras varias acaecidas en Europa (Holanda, Bélgica, Dinamarca, Vaticano y España) en los años 2013 y 2014, todas las cuales, con escasas excepciones, sucedieron en similares circunstancias del momento de la abdicación (entre 2013 y 2014), la edad del abdicante (entre 75 y 85 años) y la edad de los sucesores (entre 43 y 54 años, salvo en Ciudad del Vaticano).

Un autor cualificado ve una posible contradicción en el hecho de que el Rey abdicante sancione la ley orgánica en la que se instrumenta jurídicamente dicha abdicación pues parece convertir un acto personalísimo en bilateral ${ }^{45}$. Ahora bien, no se trata en absoluto de un acto personalismo. Nada de lo que afecta el Rey en cuanto Rey, esto es, en cuanto Jefe del Estado, puede ser estrictamente personal y privado, sino necesariamente público; más aún: estatal. Y la abdicación es un acto de primerísima naturaleza estatal como concerniente a la Jefatura del Estado y a la forma política concreta por la que optó el constituyente.

El mismo autor muestra inquietud sobre qué sucedería si las Cortes se negaran a aprobar la Ley Orgánica, de abdicación, dado que la aprobación no es un acto debido ${ }^{46}$. Sucedería que no habría abdicación, dado que la aprobación de la ley orgánica no es un acto debido de las Cortes Generales y la abdicación quedaría sin el instrumento jurídico constitucionalmente requerido. Esto, con seguridad, originaría serios problemas, pero no cabe otro dictamen jurídico. Es sorprendente que este asunto y los demás mentados en el artículo 57.5 de la Constitución no hayan merecido hasta ahora la atención del legislador orgánico. Por eso le dedico unas líneas en el epígrafe final del presente trabajo.

45 Dí́zz Revorio, F. J.: «Los retos de la monarquía parlamentaria en España: adaptarse a los tiempos sin renunciar a su sentido histórico y a su esencia legitimadora constitucional», Parlamento y Constitución, Anuario, Cortes de Castilla La Mancha y Universidad de Castilla La Mancha, n. ${ }^{\circ}$ 16, 2014, pág. 174, nota 58 .

46 Ibiden, lug. cit. 


\section{DE PRÍNCIPE HEREDERO A FELIPE VI}

\subsection{Aprendizaje del oficio}

Durante el proceso constituyente, Don Juan Carlos apenas contactó con la Ponencia Constitucional, ni después con los jefes de fila, salvo para hacerles llegar a aquellos y a estos su preocupación por mantener como sucesor al ya entones Príncipe de Asturias Don Felipe de Borbón. Acaso sí tuviera algún contacto mayor con los senadores de nombramiento regio, los cuales, por razones obvias, habrían de ser muy receptivos a sus sugerencias. Sugerencias que, parece que no fueron nunca más allá del título II, relativo a la Corona y en particular al orden sucesorio.

En cuanto al sistema sucesorio, se reprodujo el histórico, que establecía, y sigue haciéndolo, el principio de varonía, esto es, la preferencia del varón sobre la mujer, lo cual confirmaba a Don Felipe como sucesor aun siendo de menor edad que sus dos hermanas. Si ese era el propósito, su reflejo en el texto constitucional no pudo ser más disfuncional puesto que cabía (y se propuso en varias enmiendas en el Senado, cuales fueron la de la Entesa dels Catalans y la de Villar Arregui) una solución alternativa que respetaba esa prioridad ya ganada, que nadie tenía interés en alterar, y quedaba para lo sucesivo un sistema no discriminatorio. Con el tiempo la opinión pública se manifestó contraria a la solución adoptada.

En los últimos años de su reinado, Don Juan Carlos cedió protagonismo a su sucesor, principalmente en el ámbito internacional, y más concretamente en las estrechas y amistosas relaciones con la Comunidad Iberoamericana. No obstante, la «solución» adoptada desde 1997 consistió en publicar un decreto que le confería la representación de España en el acto correspondiente (la toma de posesión de un nuevo presidente $)^{47}$ fue muy discutible porque colocaba al Heredero a las órdenes del ministro de Asuntos Exteriores. En la recta final del mandato de Juan Carlos I, debido a sus dificultades de salud, el Heredero cumplió una agenda cercana a la de Jefe de Estado, salvo la recepción de embajadores y alguna otra función. Todo ello sirvió para que el Heredero llegara al reinado con cierta madurez y buen rodaje.

\subsection{Una monarquía renovada para un tiempo nuevo}

Felipe VI, en el discurso de su proclamación, habló significativamente de «una monarquía renovada para un tiempo nuevo» describiendo en sendos párrafos el papel de la Corona:

«La Corona — dijo- debe buscar la cercanía con los ciudadanos, saber ganarse continuamente su aprecio, su respeto y su confianza... velar por la dignidad de la institución, preservar su prestigio y observar una conducta íntegra, honesta y trans-

${ }^{4}$ Cfr. Mi estudio El Príncipe de Asturias. Su estatuto jurídico, Congreso de los Diputados, Madrid,

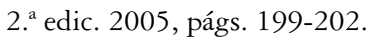


parente... Porque, solo de esa manera, se hará acreedora de la autoridad moral necesaria para el ejercicio de sus funciones. Hoy, más que nunca, los ciudadanos demandan con toda la razón que los principios morales y éticos inspiren —y la ejemplaridad presida - nuestra vida pública. Y el Rey, a la cabeza del Estado, tiene que ser no solo un referente sino también un servidor de esa justa y legítima exigencia de todos los ciudadanos ${ }^{48}$.

Junto al bagaje con el que la Corona se inserta en el sistema político, hizo una referencia a su función constitucional: «La independencia de la Corona, su neutralidad política y su vocación integradora ante las diferentes opciones ideológicas, le permiten contribuir a la estabilidad de nuestro sistema político, facilitar el equilibrio con los demás órganos constitucionales y territoriales, favorecer el ordenado funcionamiento del Estado y ser cauce para la cohesión entre los españoles. Todos ellos, valores políticos esenciales para la convivencia, para la organización y desarrollo de nuestra vida colectiva» $^{49}$.

Entre las primeras medidas adoptadas por Felipe VI han destacado por su seriedad y por su mejor o peor acierto :

1. Reorganización de la Casa y Familia de S. M. el Rey

— Reducción de la Familia Real a la estrictamente nuclear.

- Revocación del Ducado de Palma que ostentaba el matrimonio Urdangarín-Borbón, como una medida más que afecta a la relación entre los dos hermanos, con motivo de la investigación que, por delitos contra la Hacienda Pública, sufrió ella y ha sido condenado él.

- Control de gastos de la Casa del Rey y transparencia en su gestión, asemejándola, no del todo, a la Administración Pública ${ }^{50}$.

2. Reacción (algo tardía) ante el despropósito generado respecto de la (no) investidura de ningún candidato como Presidente del Gobierno en 2016, extremo al que dedico en el último epígrafe algunas líneas y sugiero algún retoque.

3. Reacción ante el grave problema generado por el movimiento independentista catalán, el más grave no ya de su reinado, sino desde 1975, al que me referiré mas adelante.

${ }^{48}$ Discurso de su Majestad Felipe VI en su proclamación ante las Cortes Generales (22-VI-2014). Cfr. Herrero de MiÑón, M.: «Los mensajes regios», en VV. AA.: Libro homenaje a Jaime Guasp, Madrid, 1984, págs. 315-324; GonZALO, M.: «Consideraciones sobre los mensajes y discursos del Rey», en VV. AA.: La Monarquía Parlamentaria, Congreso delos Diputados, Madrid, 2001, págs. 88 ss.; del mismo autor y Tenorio SÁnCHez, P. J.: «La Corona en los discursos parlamentarios del Rey», en TorRES DEL Moral, A. (dir.): Monarquía y Constitución, Colex, Madrid, 2001, págs. 627 ss.

49 Discurso de su Majestad Felipe VI... cit., mismo lugar.

50 Cuando se dan estas páginas a la imprenta no hay aún sentencia del Tribunal Supremo sobre el recurso que el Sr. Urdangarín interpuso contra la condena que le ha impuesto el Tribunal Superior de Islas Baleares. 
Por muchas diferencias que quieran encontrarse entre Juan Carlos I y Felipe VI, o que existan en realidad entre ellos, obviamente las referentes a sus respectivas formaciones intelectuales y talantes personales, hay una semejanza importante; más que semejanza, igualdad. Consiste en profesar ambos un concepto muy preciso del significado y alcance del tipo de monarquía parlamentaria que aquel desempeñó y que este lo hace ahora, en la cual el Rey no juega a político porque no debe; no debe porque no es un político y no es un político porque su estatuto jurídico lo coloca al margen de la contienda política. Su irresponsabilidad e inviolabilidad así lo determinan porque, en un Estado democrático de Derecho, quienes ejercen el poder asumen la correspondiente responsabilidad política y quienes asumen responsabilidad política ejercen el poder. Lógicamente vale igual decirlo en forma negativa: quienes no tienen responsabilidad no tienen poder, etcétera.

\section{CRISIS CATALANA Y DERECHO DE MENSAJE}

El derecho de mensaje no está expresamente atribuido al Rey ni por el texto constitucional ni por una ley y, sin embargo, lo ejerció Juan Carlos I desde un principio y, una vez aprobada la Constitución, siguió con la misma practica. Felipe VI ha continuado con el precedente y ni entonces ni ahora ha habido objeción alguna ${ }^{51}$. Puede considerarse, por tanto, que forma parte del Derecho constitucional español como una convención o una costumbre constitucional ${ }^{52}$.

Ya hemos recordado en una página anterior la intervención de Juan Carlos I en la frustración del golpe de Estado Armada-Milans-Tejero del 23 de febrero de 1981, más conocido por su fecha en siglas: 23-F. Tomó las riendas del asunto y, con el arma de comunicación en aquellos momentos más útil, el teléfono, fue calmando a unos, convenciendo a otros y advirtiendo a alguno. Aquello terminó con soldados saliendo del edificio del Congreso de los Diputados por las ventanas mientras otros firmaban el nunca bien investigado "pacto del capó». Pues bien, uno o dos días más tarde el Rey citó en Zarzuela a sendos líderes de los principales partidos políticos de implantación nacional: Adolfo Suárez, Felipe González, Santiago Carrillo y Manuel Fraga y los instó a que pusieran todo su empeño en impedir episodios como el vivido.

De modo similar, treinta y seis años más tarde, el día 3 de octubre de 2017, Felipe VI asumió el problema constitucional de primerísimo orden creado por el independentismo catalán y agravado por la horrenda jornada de la antevíspera durante la celebración de un referendo ilegal, inconstitucional, fraudulento y sin garantías, no obstante lo cual los diputados independentistas validaron un resultado de imposible verificación y lo consideraron como suficiente y habilitante para proclamar la secesión de Cataluña res-

51 Cfr. mi trabajo «Sobre la Monarquía como forma política de la Jefatura el Estado y su simbolismo», en VV. AA.: CEPC, Madrid, 2018, actualmente en prensa.

52 Cfr. GONZÁLEZ TREVIJANO, P.-J.: La costumbre en Derecho constitucional, Congreso de los Diputados, Madrid, 1989. 
pecto del Estado español. Ante la falta de reacción del Presidente del Gobierno, el Rey adoptó, en un medido discurso, una posición muy severa. Inmediatamente surtió efecto: los más heterodoxos, para rechazarlo por motivos pretendidamente ortodoxos; los políticos del común, para ensalzarlo por hacer lo que ellos no habían sabido; la ciudadanía, para tranquilizarse sabiendo que hay un Jefe del Estado. Días más tarde, en la ceremonia de entrega de los Premios Princesa de Asturias y espectacularmente arropado por celebridades mundiales, entre las cuales no faltaban jerarcas de la Unión Europea, insistió en la gravedad de la situación pero rebajó el tono severo en favor de consideraciones jurídico-políticas igualmente medidas pero que ya no necesitaban del tono secante de la vez anterior: la advertencia ya estaba hecha y era hora de asomar una voluntad de superación que nunca había faltado, como tampoco faltaba ahora el nítido mensaje de que estaba dispuesto a seguir ejerciendo la Jefatura del Estado.

Así queda en su sitio la monarquía parlamentaria española: seria, positiva, constitucional y receptiva. Pero quedan asimismo en su sitio las instituciones que tienen asignados los poderes efectivos del sistema parlamentario de gobierno y también los partidos que hacen política en ellos.

No está mal que el Rey tenga "partidarios», siempre que él no los distinga con sus preferencias, o simplemente que haya ciudadanos que le concedan su personal confianza, a la que él debe responder únicamente con su trabajo. Y está bien porque el Rey no debe ser una reliquia intocable, ni tampoco un dios olímpico que de vez en vez pronuncia una sonora sentencia; mucho menos el representante laico de Dios en la Tierra, como otrora se defendió con el silogismo y con la espada. Eran otros tiempos. Como persona de hueso y carne, seguro que le halaga verse vitoreado en ocasiones concretas. Pero de ahí a que el Rey tome las riendas de la política autonómica del Estado, utilice los mecanismos habilitados por el artículo 155 constitucional (acaso el único precepto jurídico conocido por su número) y «arregle el problema catalán» a base de discursos televisivos va un trecho considerable. Empujarlo a tal actitud sería contraproducente si no fuera inútil. Contraproducente porque equivaldría a erigirlo (o pretenderlo al menos) en político activo con el correspondiente desgaste de su persona y de la institución que encarna; inútil porque sabe que no puede dejarse convencer para actuar así. La excepción no debe hacer regla.

En efecto, ese cometido corresponde al Presidente del Gobierno, como director de la política nacional e internacional del Estado español. Un Presidente del Gobierno leal al Rey y a la Constitución no debe dar lugar, por su falta de iniciativa, a la repetición de tal escena. Como hace ya algunos años escribió Alvarado Planas, «la pervivencia de la institución monárquica cobra sentido en la actualidad en la medida en que satisfaga su vocación simbólica, es decir, histórica, y prolongue solo los aspectos positivos del instituto» ${ }^{53}$.

53 Alvarado Planas, J.: «La Corona como símbolo», en Torres del Moral, A., y Gómez SÁNCHEZ, Y. (coords.): Estudios sobre la Monarquía, UNED, Madrid, 1995, pág. 98. 


\section{DOCE RETOQUES A LA INSTITUCIÓN}

\subsection{Planteamiento}

Se atribuyó a Kissinger, el que fuera Secretario de Estado norteamericano bajo la presidencia de Nixon, la máxima de que, para resolver un problema, lo primero que hay que hacer es crearlo. Mejor será que nos olvidemos de tan brillante idea a la hora de encarar una posible reforma constitucional en los tiempos actuales, cuando soplan vientos de cambio. Lo prioritario es inventariar los problemas existentes,

Los dos partidos hasta ahora hegemónicos se han resistido durante casi cuarenta años a reformar la Constitución olvidando que solo se reforma lo que se quiere conservar. Ahora se acumulará el trabajo porque, por lo que se publica en los medios, no hay título, capitulo o precepto sobre el que no ondee la bandera reformista. Apenas nadie discute la necesidad de hacer modificaciones en nuestra norma suprema, pero las dudas comienzan a la hora de elegir la estrategia adecuada: si una sola operación que se extienda a todo el texto constitucional, o que abarque varias zonas del mismo, o bien sucesivas reformas parciales sobre materias concretas y según vaya sintiéndose su necesidad y urgencia y se logre el consenso favorable de los partidos y de la ciudadanía.

La monarquía no es una excepción. Entre otros motivos, porque el título II adolece de no pocos pasajes mejorables aunque sólo sea para completarlos. En varias ocasiones, cuando menos riesgo había de que se tergiversara la operación, me he pronunciado sobre la necesidad o al menos pertinencia de actualizarlos y perfeccionarlos. Y, conforme ha ido madurando el cumplimiento y desarrollo de la Constitución con el correspondiente funcionamiento de los poderes públicos, he visto incrementarse los aspectos susceptibles de reforma o complemento. Si en un principio indiqué solamente tres pasajes, luego fueron aumentando hasta ser más del cuádruplo.

Las modificaciones que propongo son de desigual envergadura y urgencia, por lo que la o las decisiones reformadoras deben ser adoptadas con la prudencia política propia de operaciones delicadas. En primer lugar, debemos distinguir entre las que exigen reforma constitucional y las que pueden hacerse operando sobre normas de rango legal. Pueden hacerse, digo, pero nada impide que todas o cada una de ellas se integren en operaciones de reforma constitucional. No es cuestión jurídica, sino política, de cálculo y prudencia política.

De una parte, hay que valorar la mayor facilidad de la vía legislativa que de la constitucional, sobre todo si sobre esta pesa la muy real expectativa de ser sometida a referendo nacional. De ser así, como lo asegura quien puede hacerlo, es preferible una sola operación reformista sobre todos los preceptos que puedan mejorarse en vez de hacerlo por partes y tener que convocar sucesivos referendos.

De otra, hay que despejar las dudas acerca de si determinados preceptos requieren reforma o basta con una interpretación adecuada. Sean, por ejemplo, los artícu- 
los 99 y 62h. Desde luego, una interpretación conforme al principio democrático puede resolver problemas sin acudir al siempre más costoso procedimiento reformador.

Veámoslos con sendos breves comentarios y comenzando por las más simples.

\subsection{Sin necesidad de reforma constitucional}

1. La promulgación, de un estatuto jurídico del Príncipe heredero que dé cobertura a su actividad pública, la cual, cuando Felipe VI lo era, fue continua y abundante. Pues, en efecto, está por resolver el problema de las eventuales responsabilidades derivadas de dicha actividad, como he estudiado detenidamente en otra publicación ${ }^{54}$. Ahora bien, no se hizo durante el reinado de Juan Carlos I y ahora es menos urgente dada la temprana edad de la Heredera, lo que no significa, sin embargo, que no se le preste la debida atención, ni haya falta de diligencia legislativa; se debe al juicio erróneo de que dicho estatuto jurídico es innecesario. Cuando se haga, si se hace, bastará, a mi juicio, una ley orgánica de un par de artículos.

2. De igual modo y con igual pertinencia de una ley orgánica, deberán ser promulgados el estatuto jurídico de la Reina consorte y del consorte de la Reina. Las funciones (no constitucionales y no escritas) que han ejercido y siguen ejerciendo son suficientemente elocuentes de la conveniencia de esta medida. Pero lo decisivo es la posibilidad de que dicha persona sea nombrada tutora del Rey menor y, sobre todo, que acceda a la Jefatura del Estado como Regente, esto es, a ejercer la Jefatura del Estado, por interina que esta sea; todo ello conforme a la previsión de los artículos 59 y 58 respectivamente de la Constitución. Hace tiempo que los poderes públicos deberían haberse persuadido de la conveniencia (si no estricta necesidad) de dotarlos de un estatuto acorde con su condición, independientemente del que les corresponda, en su caso, como Regentes. Baste un argumento adicional: para ser tutor del Rey menor se exige que el interesado permanezca en su estado civil de viudez; en cambio, el similar artículo 58 no dice nada sobre la Regencia. No hace falta que describa el descalabro que podría producirse.

3. Dígase lo mismo respecto de las personas integrantes del orden sucesorio y tienen, por tanto, expectativas de sucesión en la Corona. Aunque este supuesto es menos probable que los contemplados anteriormente ${ }^{55}$, no deja de ser una posibilidad que el legislador debe regular.

54 Cfr. mi estudio El Príncipe de Asturias. Su estatuto jurídico, Congreso de los Diputados, Madrid, 2. ${ }^{\text {e edic., } 2005 .}$

55 Si es cierto, como se dijo, que Felipe VI estuvo dispuesto a renunciar a su derecho sucesorio si no era apoyado en su decisión matrimonial, ahí tenemos una ocasión en la que se habría hecho realidad la hipótesis que comentamos. 
4. Se halla la doctrina muy dividida respecto del apartado quinto del artículo 57, en buena parte debido a su oscura, si no deficiente, redacción, que habla de una ley orgánica, en singular, cuando han de ser varias a fin de:

4.1. Regular el procedimiento general de abdicación de la Corona.

4.2. Regular el procedimiento de renuncia de los derechos sucesorios o meras expectativas.

4.3. Resolver las dudas sucesorias de hecho y de Derecho ya existentes y de las que se estime que pudieren presentarse en el futuro.

4.4. Confeccionar un orden sucesorio breve e inequívoco; aunque el precepto no menciona esta cuestión, no deja de ser igualmente relevante a fines de seguridad jurídica.

5. La Casa del Rey, creada en 1975 y remodelada después, goza de una garantía institucional por cuanto está mencionada en el texto constitucional, concretamente en el artículo 65, lo cual impide su supresión. Desde hace ya algún tiempo se siente la necesidad de promulgar un Estatuto de la Casa con rango normativo superior a una simple disposición reglamentaría del Gobierno ${ }^{56}$. Tal estatuto debería regular cuestiones como:

a) los mecanismos de impugnación contra actos y disposiciones de Jefe de la Casa;

b) el régimen jurídico del refrendo de los actos del Rey en materia de gestión interna de la Casa, que, a mi juicio, debe corresponder a su Jefe.

c) El régimen económico-financiero-contable de la misma, y

d) Las relaciones externas de la Casa con otros órganos e instituciones tanto públicos como privados.

De esta manera, la Casa, en cuanto órgano administrativo tendría delimitados su organización y funcionamiento conforme a los principios constitucionales de legalidad y de plenitud de control jurisdiccional ${ }^{57}$.

6. Aunque, para evitar una errónea interpretación de la frase «se tramitarán sucesivas propuestas...», que figuran en el apartado 4 del artículo 99 de la Constitución, como ya ha sucedido con ocasión del fallido procedimiento de investidura habido en 2016, se puede desdoblar dicho apartado del siguiente modo:

Art. 99.4: «Si efectuadas las citadas votaciones no se otorgase la confianza para la investidura, procederá hacer nuevas consultas conforme a lo dispuesto en el apartado primero y a los mismos efectos».

${ }^{56}$ Cfr. mi trabajo «Regeneración dela Monarquía», en Arnaldo AlCubilla, E., y GonZÁLEZ-Trvijano, P. (dirs.): En pro de la regeneración política de España, Fundación Universidad Rey Juan Carlos y Fundación Canal (Canal de Isabel II), Madrid, 2015, págs. 431-433.

57 Vacas García-Alós, L.: La Casa de S. M. el Rey, CEPC, Madrid, 2002, págs. 126-127, 154-155, 159 y $2009-2010$. 
Art. 99.5: «Si, transcurridos dos meses desde la primera votación de investidura, o de tres meses desde la renovación del Congreso de los Diputados, sin que ningún candidato obtenga su confianza, el Rey disolverá...»

No obstante, la rectificación del apartado 4 puede ser suplida mediante una sencilla interpretación lógica y teleológica, como propuse en su momento y finalmente se hizo en 2016. Y, en cuanto al eventual apartado 5, también puede solventarse sin reforma constitucional añadiendo, con igual redacción, un apartado tercero al artículo 172 del Reglamento del Congreso de los Diputados.

\subsection{Con obligatoria reforma constitucional}

7. Establecer en el artículo 57.1 la igualdad sucesoria entre el hombre y la mujer, disponiendo además que todas la alusiones constitucionales al Rey, en masculino, deben entenderse hechas indistintamente al Rey y a la Reina titulares de la Corona; o bien llevar esta precisión a una disposición adicional. Ciertamente, tras la abdicación de Juan Carlos I y proclamación de Felipe VI, esta medida ha dejado de ser urgente por varios años, lo que, sin embargo, no debe entenderse como una invitación al olvido.

En el informe del Consejo de Estado y estudio del Centro de Estudios Políticos y Constitucionales se aportó una redacción alternativa aceptable de dicho precepto, la cual, sin embargo, no prevé que, por la vía de los sucesores, pudiera(n) llegar al Trono alguna(s) persona(s) que pocos quisieran ver ni imaginar. Además, la vía de los sucesores, Código Civil mediante, es prácticamente inextinguible, con lo que el artículo 57.3, que prevé la participación, en su caso, de las Cortes en la sucesión, resultaría ser de aplicación imposible, contra la voluntad expresa del poder constituyente.

A mi juicio, una redacción alternativa que tenga en cuenta la eventualidad anterior, podría tener el siguiente tenor literal:

«La Corona de España es hereditaria en los descendientes en línea recta, y habidos en legítimo matrimonio, de S. M. Don Juan Carlos I de Borbón, legítimo heredero de la Dinastía histórica. La sucesión en el Trono seguirá el orden regular de primogenitura y representación, siendo preferida siempre la línea anterior a las posteriores; en la misma línea el grado más próximo al más remoto, y en el mismo grado la persona de más edad a la de menos».

8. Con la finalidad de evitar interpretaciones desviadas, se debe cambiar la redacción del artículo 62. h) para hacer más evidentes, si cabe, las respectivas posiciones del Rey y del Gobierno en cuanto a sus respectivas relaciones con las Fuerzas Armadas. Podría adoptar el tenor siguiente o similar:

«) «...sin perjuicio de las competencias que la Constitución confiere en este ámbito». 
9. Resulta aconsejable y más acorde con el actual Derecho internacional, que el apartado tercero del artículo 63, que habilita al Rey para declarar a guerra y hacer la paz, sea suprimido por estar en contradicción con la prohibición de tales declaraciones por parte de Naciones Unidas y en cierta disonancia con el propio Preámbulo constitucional, que dice ser voluntad de la Nación española «[c]olaborar en el fortalecimiento de unas relaciones pacíficas y de eficaz cooperación entre todos los pueblos de la Tierra».

10. Extender el refrendo a los actos regios regulados por el artículo 65 (administración y nombramientos internos de la Casa de S. M. el Rey), lo cual afecta a varios preceptos: los dos apartados de dicho artículo y también, para la necesaria concordancia, los artículos 56.3 y 64.1. He aquí una aproximación a tal operación:

a) Artículo 65.1: «El Rey recibe de los Presupuestos del Estado una cantidad global para el sostenimiento de su Familia y Casa y la distribuye».

b) Artículo 65.2: «El Rey nombra y releva a los miembros civiles y militares de su Casa».

c) Art. 56.3: Suprimir el último inciso («salvo lo dispuesto en el artículo $65 »)$.

d) Art. 64.1: Añadir «El nombramiento del Jefe de la Casa de S.M. Rey será refrendado por el Presidente del Gobierno. Los demás actos previstos en el artículo 65 serán refrendados por el Jefe de la Casa de S.M. el Rey».

11. Como el tiempo pasa de modo inmisericorde, de vez en vez la opinión pública repara en algún aspecto del estatuto de la Corona que, teniendo a su favor la tradición de siglos, se acomoda difícilmente a la sensibilidad y a las demandas de una sociedad cada vez más autónoma y acomodada a la aconfesionalidad del Estado. Me refiero al preconcepto subyacente o valor entendido por el constituyente acerca de las creencias religiosas de los miembros de la Dinastía o de la recia vinculación histórica entre la monarquía española y el cristianismo primero y el catolicismo después.

Seguramente en 1978 no era motivo de preocupación y, de haberlo sido, quizá no fue prudente afrontar lo que nunca, a lo largo de la Historia, había presentado dificultades jurídicas ni políticas, e incluso habían beneficiado la solidez de las correspondientes dinastías. Si, por las dificultades existentes entonces, 1978 no era el momento de cuestionar tales extremos, ahora sí lo es. Y la conclusión es que deben evitarse los elementos religiosos en ciertos actos y ceremonias en los que participan el Rey o los miembros de la Familia Real. A un Estado aconfesional le corresponde una sobria equidistancia de la Corona en este ámbito, sin perjuicio de la práctica religiosa privada de sus miembros.

12. Acaso no sea impertinente ultimar esta reflexión evocando la figura japonesa del Delegado del Tennô, que no coincide con la de nuestro Regente y que por su ductilidad puede resultar muy funcional. No existe tal instituto entre nosotros y acaso fuera una prudente alternativa a la Regencia por inhabilitación del monarca, 
decisión que, por deferencia con el Rey, es más penoso adoptar. Los nombramientos que el Gobierno ha hecho durante años para el Heredero a fin de que representara a España en determinados actos (sobre todo, en tomas de posesión de Presidentes de Estados hispanoamericanos) no es la mejor fórmula imaginable por razones dichas en páginas anteriores. La actual circunstancia de que la Heredera sea menor de edad aporta otro argumento a favor de la incorporación de esta figura al Ordenamiento constitucional español. Aunque tal reforma no parece urgente, llegarán a presentarse de nuevo los mismos supuestos que durante el reinado anterior y, cuando así ocurra, debería haber preparada una respuesta jurídica satisfactoria ${ }^{58}$. Para ello debe incorporarse un apartado sexto al artículo 59, que rece del siguiente tenor literal o similar:

«6. Se instituye la figura del Delegado del Rey para sustituciones breves que no requieran la incorporación del Regente».

No se percibe, sin embargo, que haya voluntad política de afrontar alguna de las doce tareas descritas.

Title:

Forty years of Parliamentary Monarchy

\section{Summary:}

1. Introduction. 2. From the Francoist Dictatorship to the establishment of the monarchy. 3. Monarchy and demolition of the Franco regime. 4. Monarchy and Constitution: 4.1. The Monarchy after the promulgation of the Constitution. 4.2. Succession system. Oath. 4.3. Monarchy and Armed Forces. 4.4. Inviolability and International Criminal Court. 5. Monarchy and public opinion. 6. Abdication of Juan Carlos I. 7. From Crown Prince to Felipe VI: 7.1. Apprenticeship. 7.2. A monarchy renewed for a new time. 8. Catalan crisis and message right. 8. Thirteen touches to the Institution: 8.1. Approach. 8.2. No need for constitutional reform. 8.3. With mandatory constitutional reform.

${ }^{58}$ Es singular la relación que existe entre la sociedad japonesa y la figura del Tennô y la Familia Imperial. Conforme la Constitución de 1946, el Emperador es símbolo del Estado y de la unidad del pueblo, referente cultural constante de este. Pueblo y Tennô han ido adaptándose a los nuevos tiempos pero manteniendo también las tradiciones propias de la monarquía más antigua del mundo. Cfr. RodRíGUez ARTacho, S.: La Monarquia en Japón, CEPC, Madrid, 2001, passim, y «La monarquía en Japón: El marco jurídico en torno a la figura del Tennô», en Torres del Moral, A. (dir.): Monarquía y Constitución, ob. cit., págs. 117-122. 


\title{
Resumen:
}

En este artículo se ofrece una balance de la monarquía española durante 40 años, desde la sucesión de Franco Bahamonde por Juan Carlos I hasta la abdicación y la sucesión de Felipe VI. Por último se hace una propuesta de reforma constitucional en catorce puntos.

\begin{abstract}
:
In this article we offer a balance of the monarchy Spanish for 40 years, since the succession of Franco Bahamonde until the abdication of Juan Carlos I and the succession of Felipe VI. Finally, a proposal for a constitutional amendement is made in thirteen points.
\end{abstract}

\section{Palabras clave:}

legitimidad, monarquía, Constitución, opinión pública, abdicación, Cataluña, Corte Penal Internacional, derecho de mensaje.

\section{Keys words:}

legitimacy, monarchy, Constitution, pulic opinion, abdication, Catalonia, International Criminal Court, right of message. 